\title{
Paideusis
}

\section{The Ethics of Writing: Derrida, Deconstruction, and Pedagogy}

\section{Ursula A. Kelly}

Volume 14, Number 1, 2001

URI: https://id.erudit.org/iderudit/1072824ar

DOI: https://doi.org/10.7202/1072824ar

See table of contents

Publisher(s)

Canadian Philosophy of Education Society

ISSN

0838-4517 (print)

1916-0348 (digital)

Explore this journal

Cite this review

Kelly, U. (2001). Review of [The Ethics of Writing: Derrida, Deconstruction, and Pedagogy]. Paideusis, 14(1), 48-51. https://doi.org/10.7202/1072824ar viewed online.

https://apropos.erudit.org/en/users/policy-on-use/ 


\section{The Ethics of Writing: Derrida, Deconstruction, and Pedagogy by P. P. Trefonis}

\section{Ursula A. Kelly, Memorial University of Newfoundland}

Early in this book, Trefonis scolds those who speak authoritatively of Derrida and deconstruction, yet whose commentary reveals a superficial knowledge of Derrida's work. He submits that such "uninformed opinion" posing as expert commentary promotes "a conservative reading of deconstruction without sufficient depth for the expedient purpose of convenient generalizations or harried cooptation" (p.10, n.29). As a result,

deconstruction has been represented by many critics, theorists, and philosophers, unable or unwilling to take an account of and provide an accounting for (original italics) its ethical and political implications, preferring instead to eschew or disregard both its effectivity in responsibilizing the principles of action or its informing and questioning of the reason of pragmatic utility (p.179).

No such accusation could be directed at Trefonis. The Ethics of Writing is a careful, thoughtful, and nuanced reading of those texts of Derrida which are most obviously concerned with educational theory and philosophy, texts which Trefonis argues have received insufficient scholarly attention. His purpose: "to show through and by example how the radical polemics of deconstruction has value for analyzing the ethical and political implications of pedagogical contingencies of theory and practice (original italics) (p.7).

The Ethics of Writing contains a "polemical introduction" and five chapters. Only the second chapter, along with most of the introduction, is previously published material. Each chapter is carefully introduced, meticulously argued, and provides a substantial examination of major issues in contemporary philosophy (of education) and the place of Derridean thought therein. The refusal to compromise complexity or to circumvent perplexity is a strength of this writing. Its eloquence, depth, and profundity offer a sober reading of the as yet not (or ever) fully fathomable implications of deconstruction for contemporary philosophy, ethics and politics of, in this case, education. In its method, it epitomizes a rethinking of "the grounds of academic responsibility" (p.179) and, in its manner, it forms a convincing reply "to the inescapable summons to responsibility demanded of an intellectual undertaking thoroughly inscribed by and inscriptive of the conditional effects of a gradual, though steady, intensification of the ethico-political maturation of the states of theory" (p.2). 
Nor is The Ethics of Writing a case of Donald Graves meets Jacques Derrida, although those who look to this book for thoughts on (the teaching of) writing will find here no food for a diet of 'feel good' pedagogy. The deconstructionist pedagogy which Trefonis highlights challenges expressivist notions of language informed by a naive preoccupation with short-sighted, ultra-individualistic goals. Trefonis notes that Derrida's "science of a new writing" ( $p .40)$ casts suspicion on writing as authentication of self. After differance, the central notion of Derridean thought, such self-revelatory efforts are identified as "an instance of noncommunication, because in the equating of self-hood with self-presence, the Other is effaced to the point where an inner-monologue with one's 'Self' is not really an instance of transmissibility at all, but the self-deceptive verification of the desire for auto-affection. Or an attempt at the reduction of differance" (p.42).

Chapters One and Two, in particular, are substantive discussions of issues arising from modernist notions of language, writing and culture which have particular relevance in the context of a prolific public and academic (and largely acritical) attention to same. In Chapter One, "The Cultural Politics of the Sign", Trefonis presents re-readings of Derrida's re-readings of two classic texts: one, of Rousseau on the origins of language; and, another, of Levi-Strauss and his description of the Nambakwara in "The Writing Lesson". In both cases, Trefonis points to how, in the earliest writings of Derrida, "a deconstruction of the normative rendering of what it means to think, to learn, to teach, to know (original italics) begins to take root..." (P.176). Chapter Two, "The Ends of Pedagogy", is a compelling essay on Hegel and (a moment of) autobiography, "a rememoration of, and for, a curriculum" (p.54) in which, according to Derrida, "a remembrance of [Hegel's] childhood as the memory of memory itself" legitimizes certain political decisions about education in early nineteenth century Germany "by lending the credibility of intellectual support to a thesis referring to the 'proper age' for philosophy education" (p.56). Chapter Two is essential reading not only for those seeking a profound understanding of the intricacies of curricular change but for any who might question the necessity of philosophy for curriculum theory.

Readers should not turn to this book for affirmation of the end of philosophy or, for that (related) matter, the end of the university. Rather, turn to it for a renewed sense of the relationship of deconstruction and philosophy, and a redefinition of the future of philosophy and the institution of the university. Funereal tones do not abide here. Trefonis is more concerned "to breakdown [such] misinformed generalizations and stereotypes of deconstruction" (p.135). As he points out, "Derrida does not seek to denounce philosophy, to mourn and celebrate 
its death. One cannot proceed to an affirmation of a thinking of the Other by destroying the differences that bind each of them together and creates the eternal possibility of articulating a new ethical ground for knowledge and for practice" (p.182). Nay-sayers take note. Advocates proceed with caution. Superficial attempts to dismiss or applaud will be met here with unrelenting scrutiny, in keeping with the best spirit of a rigorous, reborn philosophical inquiry, what Trefonis calls, after Derrida, "a community of the question" (p.182).

In Chapter Three, "Technologies of Reason", Trefonis addresses directly, through a re-reading of Derrida's lecture, "The Principle of Reason: The University in the Eyes of Its Pupils" as "a sustained re-appraisal of the ethics of academic responsibility patterned after the principle of reason" (p.180), the basis in the writing of Derrida for a reconstitution of the university. Chapter Four, "Teaching the Other the Limits of Philosophy", focuses on debunking the myth of the end of philosophy at the hands of deconstruction. Its focus is a lecture by Derrida to the UNESCO sponsored first International Conference for Humanistic Discourse in 1994, what Trefonis calls "a mediation on the ethical ramifications of who should ask the question of the right to philosophy and where, in what space and place “. (p.136). Importantly, both chapters ponder the key question of "how deconstruction can help an institution to reconfigure itself for the better by causing those who are part of it, are it, to question the grounding of the concepts that they hold most dear as the keys to the perfectability of human being" (p.136).

One of the key contributions of The Ethics of Writing is not so much "to facilitate the breaking of new ground for thinking about the practice of pedagogy at large" (p.6), although it does edge us forward in this respect. Rather, it is the attention it brings to previously ignored or insufficiently read texts which expands the scholarly literature on Derrida and education. This contribution is twofold: It raises the profile of Derrida's educational texts which Trefonis rightly notes have fallen outside the accepted canon of Derrida's work; and, it casts a refreshingly astute educational eye on the overall project of deconstruction. The implications of what is revealed in this gaze warrant the thoughtful attention of all those interested in the future of philosophy and "the ethico-political focus of deconstruction with respect to issues of educational theory and practice in general" (p.6).

Most importantly, however, this book contributes to a breaking of the neck hold a particularly stubborn binary, that of "the opposition of Eurocentrism and antiEurocentrism" (p.136) has over much contemporary debate about philosophy and the future of the university. Trefonis warns that "[t]he Eurocentric myopia of [a] monocultural view of the archive of Western episteme is another peril of taking 
sides without actualizing sufficient precautions against the irresponsibility of academic solipsism" (p.156). To quote Derrida, "there are events, philosophical events, which cannot be reduced to this simple origin, and which meant that the origin itself was not simple, that the phenomena of hybridization, of graft, or translation, was there from the beginning..." (In Trefonis, p.156). Or, put more succinctly, "[p]hilosophy does not have a sole memory" (Derrida, in Trefonis, p.157). These insights are central to the assertion that a pedagogy of deconstruction "presupposes an affirmative answering of/to the call of the Other that, above all else, emphatically strives to hasten and improve the concrete possibilities of ushering forth a more equitable new world picture (original italics)" (p.4). In this sense, the book is invaluable in that it offers a way forward through the problematic of difference and the study of philosophy and/in the university.

In The Ethics of Writing, Trefonis succeeds in bringing renewed attention to persistent and troubling questions of philosophy and education with an unrelenting focus on "how the textuality-based machinations of the Derridean instance of deconstruction can offer a profound resistance to the instruments of domination embedded within the philosophico-institutional praxeology of teachinglearning" (p.6). This book should be of value to all those whose work or interest is in the "foundations" of education. This book will engage those who believe thought is best when unsettled; it should be required reading for those whose settled thoughts suggest a sedation or abdication of an ethics of intellectual responsibility at a perilous moment in the history of education. As Trefonis studiously demonstrates throughout this book, it is time to rethink the future, to rethink what it is we think we know, beginning with the ethical challenge of "looking backwards to the memory of the past and rearticulating the terms of our responsibility to what happened before"(p.183). And, if Trefonis is correct that "a question is like a prayer: its hope needs to be answered" (pp. 165-6), it is also time to rethink deconstruction and its relationship to the best hopes and prayers of education.

\section{References}

Trefonis, P.P. (2000). The Ethics of Writing: Derrida, Deconstruction, and Pedagogy.

Rowman \& Littlefield Publishers, 200 pp. ISBN 0-8476-9558-1 (pbk.) 


\section{Sexual Ideology and Schooling by Alexander McKay}

\section{Paul O'Leary, University of Western Ontario}

One of the pearls of wisdom I received when a mere boy, was that one should never discuss matters of religion or politics with others since this would inevitably give rise to disagreements as well as mutual ill-will. It was however, deemed unnecessary to give the same sort of advice concerning discussions about sex since in those tight-lipped days one did not, at least in front of the children, acknowledge the existence of such goings-on. In these more talkative days however, the subject matter of sex provides all manner of expert with an endless supply of material. Nevertheless disagreement and ill-will are in no way diminished despite this more liberal outlook. And when it comes to sex education ill-will veers towards the apoplectic. Alexander McKay's Sexual Ideology and Schooling recognizes the deeply controversial nature of what he calls sexuality education, but in no way does he accept as wisdom, the idea that human sexuality should be treated as a nondiscussable item within the curriculum of public schools. But how can coherent and defensible programmes about human sexuality be provided without taking sides on various conflicting views about the nature and function of sexuality within human life?

One answer to this question has been to adopt what McKay calls the "BareBones Approach"(p.88). This approach, which is the educational administrator's version of "safe sex", avoids any topics which are controversial within the community at large. Programmes which reflect this approach tend to reduce subject content to safe issues such as reproductive biology and virology. While this may avoid controversy, it also has the unfortunate feature of not fostering students' deliberative powers on matters of significance within their lives. As far as McKay is concemed, the Bare-Bones Approach to sexuality education is a non-starter.

If we cannot take the safe road of non-controversiality, does this mean that we must choose between a Restrictive approach to teaching about human sexuality or a Permissive one? These two approaches are based on two different and conflicting evaluations of the role of sexuality within human life. What McKay calls the Restrictive ideology, is historically connected to the Judaeo-Christian tradition, and tends to take a rather dim view of any sexual conduct disconnected from marriage and procreation. Besides, sex is a rather nasty business in any case, and is in need of control by rules which are "absolutist", i.e. of the always-do or never-do variety. It is easy to see how this sort of ideology gives rise to sex education 
programmes which seek to persuade students to practice sexual abstinence, not only because it conforms to certain ethical norms, but also because it is viewed as the best means of avoiding unwanted pregnancies as well as sexually transmitted diseases. When however, we turn to McKay's version of a Permissive ideology, we see that its evaluation of human sexuality is more favourable. The Permissive outlook regards sex as either benign or a positive force. In the latter case, sex is able to provide pleasure, contribute to self-fulfilment, and foster psychological adjustment.(p.52) Ethically, a Permissive ideology does not stress fixed rules concerning sexual conduct but emphasizes mutual consent, pleasure, and respect. While McKay sees the fit between a Restrictive ideology and its educational programmes as especially close, the effect of a Permissive ideology on sexuality education is more diffuse(p.77) although it does tend to "favour what is commonly referred to as comprehensive sexuality education".(p.64) That is, it tends to favour supporting an education that includes topics that have historically been omitted from the curriculum,e.g.homosexuality. Perhaps then, we could characterize the main difference between the two approaches to sexuality education by saying that a programme based on a Restrictive ideology fosters conformity to certain rules about sexual conduct, while one based on a Permissive ideology fosters a student's ability to make choices concerning sexual conduct.

When McKay considers the question of which of the two approaches to sexuality education we should adopt, he says that one cannot make a choice based upon a conclusive demonstration that one ideology is superior to the other. He takes the view that "sexual ideologies correspond to complex socially derived assumptions rather than a set of value free objective facts which can be easily demonstrated."(p.95) McKay sees this as providing "an initial foundation for moving away from an intellectual and sociosexual framework that pushes us to wage the war of ideological superiority towards a more pluralistic acceptance of diversity."(p.96) But, we may ask, is it necessary, in order to support "a more pluralistic acceptance of diversity" to adopt a sceptical outlook on claims about the nature and function of human sexuality? I think not. For acceptance of diversity only requires, as a bare minimum, tolerance of those others with whom one disagrees. The virtue of tolerance does not require scepticism about achieving some truths about sexual conduct; it only requires that we regard others with whom we differ as being neither knaves nor fools. Firm convictions then do not preclude having a tolerant outlook.

Perhaps a more fundamental reason McKay has for not basing sexuality education on either the Restrictive or the Permissive ideology, is that even if it turns 
out that one of them is right we are nevertheless unlikely to achieve a consensus among reasonable people about such matters. If then, we use one approach to the exclusion of the other despite the reasonableness of the excluded outlook, we are violating important principles of a democratic polity. What, according to McKay, we need is a "democratic sexuality education" which embodies both respect for pluralism and freedom of belief, while aiming at getting students to think critically about sexuality. This, claims McKay, is not another sexual ideology for it does not call upon any substantive beliefs about the nature and function of sexuality within human life. Rather it might be viewed as "meta-ideological" since it calls only upon those principles required by a democratic and pluralistic polity.

McKay's solution to the problem of how best to engage in teaching about human sexuality, rests upon viewing sexuality education as part of a student's political education. Thus he writes that "facilitating the ability to deliberate between divergent points of view is a fundamental component of political socialization in a plural democracy".(p.150) In doing this he avoids the accusation that he is making an ideological claim about the good of autonomy; he is only making claims about the sort of capacities needed by citizens in a democratic and pluralistic polity. However, a question does arise as to the range of "divergent points of view" that need to be considered as well as the range of topics. McKay does consider as possible topics such matters as sexual orientation, gender relations, and sexually transmitted diseases. But what about issues such as paedophilia, necrophilia, and bestiality? Are the latter topics to be excluded since no point of view on their behalf can present itself as reasonable? Or is it the case that unlike sexual orientation, such topics do not as yet, have a political significance worth considering? Moreover, even if a topic does have current political significance, which divergent points of view are to be considered? Is there only one way of arguing in defence of, say homosexuality and only one way of arguing against it? And if there are multiple arguments on one side of the fence, does this reflect possible disagreements on a deeper level? Should these also be brought into focus? Although answers to questions like these can have an important impact on the content and manner of sexuality education, it is unfortunate that McKay does not consider them.

There is yet another significant omission in McKay's examination of sexuality education. Given the recent attention that has been given to virtue ethics it is surprising that McKay does not consider the possible bearing that virtues such as temperance and justice can have on the content and manner of sexuality education. Is there any place to be found for the non-reflective elements which Aristotle calls ethical habituation? Or does McKay's emphasis on the fostering of the ability to 
deliberate between divergent points of view, mean that early habituation has no significant role to play, except perhaps as an obstacle to be overcome? What is the exact character of this ability to deliberate between divergent points of view? Indeed, can we deliberate at all well about our lives without having undergone, early in our lives, a successful ethical habituation?

In raising these questions I am not at all suggesting that what McKay has done is in any way poorly done. It is not. What he has given us is clear and well argued. He has not committed any sins of commission, only those of omission.

\section{References}

Alexander McKay, Sexual Ideology and Schooling, London: The Althouse Press, 1998. 